\title{
Gemelli and His Travel to the Philippines
}

\author{
David Manzano*
}

\begin{abstract}
Giro del Mondo's Volume V, by G. Francesco Gemelli Careri (1700), dedicates two books to describe several events which took place in the Philippines in 1696 as observed by the traveler. Our main goal will be to write a historical analysis of his account, underlining the importance of the Manila Galleon in the political, economic, and social life of the Philippines at the end of $17^{\text {th }}$ century.
\end{abstract}

KEY WORDS: Gemelli Careri, Giro del Mondo, Hispanoasia, Manila Galleon, Philippines, Spanish colonialism, trading routes

\section{INTRODUCTION}

Giro del Mondo by Giovanani Francesco Gemelli Careli has earned its place in posterity for its influence on Jules Verne's famous 1872 work, Around the World in Eighty Days. Nevertheless, Gemelli's work is of greater value. His account has been an exceptional source for historical accounts of diverse places in the planet such as Persia, China, and America-areas that this Italian traveler knew first hand on his journey around the globe between 1693 and 1698. The work is divided into six volumes, the last two volumes devoted to narrating the reality Gemelli encountered in the Spanish colonies overseas. Despite its importance, few Spanish writers have devoted themselves to analyze this particular period of Gemelli's travels. Among the studies we have found are Volume XIX and XX of the General History of Travels and the translations done in the twentieth century by

"Translated by Concepcion Rosales, Ateneo de Manila University.

${ }^{1}$ The complete text of this work appears for the first time in Italy in 1700. Subsequently, given its popularity, several editions and translations of the work in other languages have been produced. The original publication is the reference we have used for this article. 
Jose Ma. de Agreda Sanchez, Jean-Pierre Berthe, and Francisca Perujo. All these works almost exclusively analyze the American territories (Volume VI of Giro del Mondo), ignoring the Spanish colonies in Asia, despite the fact that one of the six volumes in Giro del Mondo focuses on the Philippines and adjoining areas (Volume V). Recently, this perspective has been corrected by a group of researchers headed by Salvador Bernabéu, who have studied the Manila Galleon account of Gemelli. Nevertheless, at present, there is no written work in Spanish ${ }^{2}$ that has investigated the travels of Gemelli in the archipelago. Consequently, the following pages will be dedicated to this task, that of deepening the political, economic, and social reality found in the first two books of Volume V, which describe the Philippines at the end of the $16^{\text {th }}$ century.

\section{HISTORICAL ANALYSIS OF GIRO DEL MONDO}

Gemelli's narration occurs between May 7 and June 29, 1696. ${ }^{3}$ During this period, his life revolved around the preparation for his travel to America. As a consequence, the Manila Galleon would be the main focus of his account. His detailed description of his perceptions of the islands helps the reader understand the Philippine reality during the Baroque century. In addition, he provides information on a number of important persons of the period as his sources of information: Juan de Morales, ${ }^{4}$ Arguelles de Oviedo, ${ }^{5}$ Fr. Antonio Borgia, ${ }^{6}$ Joaquin Assin, ${ }^{7}$ Juan de Pozo, ${ }^{8}$

${ }^{2}$ There is a translation in English of Gemelli's travels in the Philippines by Mauro Garcia.

${ }^{3}$ Francisca Perujo's paper retrocedes the date of arrival of Gemelli one day later, i.e., May 8 (Cf. Viaje a la Nueva España Estudio Preliminar). This could be due to the fact that the Spanish authorities, until the mid-nineteenth century, did not use the time zone corresponding to the Philippines.

${ }^{4}$ Gemelli narrates the ceremony of the peace treaty with the sultan of Borneo in 1685 as described to him by Juan de Morales. According to him, after the signing of the treaty, he lived in the royal quarters, at the expense of the sultan (Giro del Mondo 94).

${ }^{5}$ Oviedo relates to him the custom of the governor of Borneo (called lampuan) to seal a pact by pouring one's blood in a cup that should be drunk by him, A practice which later, would be repeated, this time, the lampuan would drink his blood (Ibid. 93-94).

${ }^{6}$ This Jesuit who occupied the post of Procurator of the Philippines narrated to Gemelli his belief in the existence of islands, rich in gold, and silver, known as the Solomon Islands (Ibid. 102).

${ }^{7}$ This Jesuit father narrated to him the funeral rites of the natives and their reluctance to eat alone (Ibid. 151).

${ }^{8}$ Gemelli cited him as an example of men who had monkeys as mascots, since these animals proliferated in the Philippines (Ibid. 160). 
Juan Serra, ${ }^{9}$ etc. These references can weaken the argument sustained by authors of the caliber of Adam Smith or William Robertson, who questioned the validity of Gemelli's account by stating that the author never left his native Italy (Smith 163; Robertson 480).

During the $18^{\text {th }}$ century, when Gemelli's work was reaping acclaim, Smith's and Robertson's thesis found support in the words of the author of Giro del Mondo's Prologue, Giosef Antonio Guerrieri. In it, Guerrieri noted his companion's desire to create a work based on writings that were in existence in distinct regions that he had visited, ${ }^{10}$ in order to create a richer text, helping the reader contextualize the realities that the Italian had depicted. Thus, numerous text passages referring to the Philippines were reminiscent of the works of Antonio de Morga (1609), the Relación de las Islas (1604) of Pedro Chirino, Labor Evangelica by Francisco Colín (1663), Historia de Mindanao by Francisco de Combés (1667), ${ }^{11}$ the work of Georg Joseph Kamel, ${ }^{12}$ and the work Noticias de las Islas Palaos by Andres Serrano (published in 1705, although since 1607, reference had been made to this work).

The last work offers interesting data that could clarify the issue surrounding the authorship of this work. Serrano wrote after the Feast of the Holy Innocents in 1696, of the arrival of 30 unidentified natives from the Palao islands on the promontory of Guiguan ("which is near the Point or Promontory formed by the island of Sama and Ybabao, where the early missions of the Jesuits are" [Serrano 1]). The following passage from the work of Gemelli is cited:

A tal proposito narraromi persone degne di fede; che gli anni passati vi capitarono alcuni, che differo, esser venuti da isole non molto lontane; una delle quali era abitata solamente da donne: e che i maschi vi vanno in certi tempi determinati, per

${ }^{9}$ This magistrate showed Gemelli a rare, dead bird that he brought from Borneo (Ibid. 163).

${ }^{10}$ According to Perujola, the greater part of his references were produced by Matteo Egizio, Doctor of Laws, archeologist, and well respected humanist, who helped Gemelli in the formulation of his work (Viaje a la Nueva España Estudio Preliminar).

${ }^{11}$ This work is cited often in the text. As a matter of fact, it is the only source he inserts within his narrative discourse (Gemelli, Giro del Mondo 163-164).

${ }^{12}$ In fact, he is mentioned as Giorgio Carrol Aleman (Ibid. 192). This Jesuit worked in the Philippines between 1688 and 1706 (the year of his death); he is known for his knowledge of Philippine flora. His influence on Gemelli is noted in the detailed description of the flora by the author. The only two illustrations that Gemelli inserted in Books I and II of volume V are probably works of Kamel. 
giacervi, e trarne I figliuoli del loro sesso. Gli Spagnuoli, per fama, la dicono de las Amazones. ${ }^{13}$ (Giro del Mondo 101)

From the start, it may seem to indicate that the Italian influenced the Spanish author in his narration or that both were influenced by the same source to relate in detail the arrival of those individuals from islands near the Philippines, that Serrano associates with the Palaos. Nevertheless, this event occurred in December of 1696, while Gemelli visited the Philippines in late spring and start of summer of the same year. Consequently, I am inclined to think (as sustained by Adam Smith) that a great number of passages in Giro del Mondo are not products of the experiences of the writer, but come from affiliated sources. The inclusion in his narrative of events after his stay in the Philippines attests to this possibility.

Setting aside the controversy, Giro del Mondo offers in its discourse interesting data on the different features of Philippine life, like its seismic problems,${ }^{14}$ its physical geography and climate, anthropological descriptions of the natives, ${ }^{15}$ proper elements of the collective imagination of the period, ${ }^{16}$ characteristics of its ecosystem, or features of the physiognomy of its cities. On the last point, given the importance of Manila and Cavite to Spanish rule, it was necessary for Gemelli to visit these cities to prepare for his trip to America. From Manila, he describes the buildings and repeated incidences of fires, due to the use of flammable materials in the design and construction, such as nipa and wood. ${ }^{17}$ He notes that Cavite

${ }^{13}$ About this subject, some bonafide persons have told me that in the past, some persons have arrived from nearby islands; one of these islands was inhabited solely by women, and during certain determinate periods, men would come to be with them and bring with them their children of the same sex. The Spaniards, came to know of this, and named it the island of the Amazons. (This and other translations hereafter are mine.)

${ }^{14}$ Among the recorded earthquakes, that which occurred on the Feast of St. Andrew in 1645 and that of September, 1625 (Giro del Mondo 125).

${ }^{15}$ Surprising data came to fore such as the fact that the "savage" natives ate rats and snakes (Ibid. 66) or the fact that children and women smoked (Ibid. 131). This latter fact is often mentioned in the chronicles of the travelers who come to the Philippines, as shown in the references in the $19^{\text {th }}$ century.

${ }^{16}$ The Italian relates the story passed on to him by José de Ourense (Recollect priest from the St. Gregory Province). The latter took a cinnamon plant in the town of Camilio (province of Camarines) and brought it to Mindanao, where the plant transformed itself into an animal. To testify to the veracity of the story, it is said that this was corroborated by Gines de Barrientos, bishop of Troy and archbishop of Manila (Ibid. 180).

${ }^{17}$ He cites the case of the destruction of the oldest church in Manila, San Agustin in 1583 (Ibid. 26) and the fire of the Royal Hospital that Gemelli dated in 1603 (Ibid. 33-34). The 
is known for its strong winds, ${ }^{18}$ and above all, for its role that it played in the development of the galleon trade from China. More importantly, it would be the point of departure for his trip to America.

Gemelli's discourse on his stay in the Philippines and his subsequent preparation for his journey mainly revolves on the journeys of the Nao (galleon), related to the Galleon trade (Giro del Mondo 88), the use of a nautical device (sesgo) to foretell the season of the vendevales, ${ }^{19}$ the many natural resources used in ship construction, ${ }^{20}$ and the indirect relationship that exists between the physiognomy of the flora and fauna of the archipelago and the Nao. ${ }^{21}$ The influence of this commercial route in the discourse of Giro del Mondo is justifiable if we take into account the belief that all that was considered Western from the Philippine perspective in the $17^{\text {th }}$ century (save for some missionaries, who did not want to share in the wealth of the rich commerce of the Pacific), was directly attributed to the galleon trade.

Many of the Westerners who arrived in the Philippines, or who wanted to go to America, travelled by the galleon. However, the Spanish Crown's concern for the islands was due to the revenue generated by the galleon trade, through the commerce with China. Europe would thus associate the Philippines with a commercial character, supported by the galleon trade from China. Consequently, the narration of Giro del Mondo, when describing Philippine reality, alludes indirectly to a series of crucial events in the development of the Manila Galleon trade. These allusions, in my opinion,

date of the fire which affected this church constructed by Antonio Herrera, was dated to 1583 by Mauro Garcia in A Voyage to the Philippines.

${ }^{18}$ These winds would cause the number of shipwrecks in 1582 and 1589 (Ibid. 247).

${ }^{19} \mathrm{Gemelli}$ describes the Vendevales period between the months of June and September, and is characterized by the existence of strong winds that cause the ships to go from one place to another (Giro del Mundo 121-122).

${ }^{20}$ These refer to wax and coconut palms that 17,000 residents of Luban paid to manufacture the embarkations from Tal, (Giro del Mondo 90-91); abaca from Cebu, (Ibid. 113); the palm leaves and the big trees found in the Philippines (Ibid. 178-179).

${ }^{21}$ Gemelli alludes to the many plants that were cultivated in the Philippines that came from Nueva Espana, thanks to the Galleon trade: "Delle frutta della nuova Spagna vi fono introdotte los Ates, Anonas, Zapotes prietos, Cicoszapotes, Aguacates, Papayas, Mameyes, e Goyavas Peruleras // From Nueva España these fruits were introduced: ates, anonas, zapotes-prietos, cisco zapotes, aguacates, zapayas, memeyes and guayabas peruleras" (Giro del Mondo 172). His account cites the arrival from Mexico of animals such as cows, horses, lambs, and turkeys. Due to the humidity, only the first two animals would propagate (Ibid. 155; 163). 
refer to the Philippine political system, the colonial policy of controlling the territories near Manila, and the basic commerce of her economy.

\section{The Philippine Political System}

Unlike in Latin America, the nearly four centuries of Spanish domination in the Philippines did not mean the installation of authoritarian rule dominated by the Spanish character. In this manner, the Philippine political system is reminiscent of the political strategies created by the Roman Empire to establish control over places distant from Rome, through a government that sought support from the elite residents. ${ }^{22}$ Certainly, the Spanish Crown established in the Philippines a politically Spanish elite (led by a Captain General). Nevertheless, his power was respected thanks to the treaties with the different communities located in the archipelago. This was depicted in Gemelli's descriptions citing the barangay chief, ${ }^{23}$ the royal leaders of the adjacent islands, ${ }^{24}$ and the mayor of the sangleys (Giro del Mondo 21).

These alliances were a key factor explaining the Spaniards' extended stay in the Philippines, although this was not the only reason. This power was strongly supported by the clergy, who disseminated to the inhabitants of the archipelago the benefits of the Iberian presence. In this manner, the scarcity of peninsulares was offset by the influence of the religious on the mind of the natives, whose power was extensive and visible in the more remote areas of the archipelago. This was shown by Gemelli, who was able to observe religious edifices in areas difficult to reach, like the lake of Bahi. The Italian praises the missionaries, given the example of his brother, the Dominican, Giovanni Battista ${ }^{25}$ and the protection extended to him by others ${ }^{26}$ in facilitating his compliance with the decrees of June 11, 1621, from the Recopilacion de Indias. This law, as Taviel de Andrade explains, bans "Westerners" from inhabiting the dwellings of the natives to avoid their exploitation.

\footnotetext{
${ }^{22}$ The flexibility of the Spanish political system has been investigated by the researcher Manuel Herrera Sanchez, in a comparative study of Dutch and Spanish political systems.

${ }^{23}$ The chief was leader of a small community of natives, respected by the Spanish authorities. According to Gemelli, this term is derived from the Malaya sailboats, called barangay (Ibid. 139).

${ }^{24} \mathrm{As}$ in the case of lampuan, cited by Arguelles de Oviedo (Ibid. 93).

${ }^{25}$ Francisca Perujo asserts this in Viaje a la Nueva España Estudio Preliminar.

${ }^{26}$ This is the case of the chaplain of the Royal Hospital of Manila, Antonio de San Pablo (Giro del Mondo 33).
} 
The influence of the religious on the subconscious of the natives was such that these easily accepted the power of the Spanish Crown through the respect for its norms. These norms emphasized the privileges enjoyed by the Spaniards in the Philippines. This is shown in Giro del Mondo, where, in alluding to the term medias - an article exclusively used by the Spaniards-one can understand up to what extent the Spanish Crown created mechanisms of social control to establish power in the Philippines. Manila was the epicenter of such power.

Manila, the capital of the region of Tondo, was to be the only city in the Islands that possessed a cabildo ${ }^{27}$ and its importance was palpable through the presence of the major institutions of temporal and spiritual power. This did not escape Gemelli, as he dedicates Chapter V of Book I for the reader to understand Manila's organization, which he describes in the following manner:

Avvegnachél' Isole Filippine siano molto da Europa discoste, e massimamente dalla Corte del Cattolico RèI N.Signore, (al quale felicemente ubbidiscono) non lasciano però d'essere ottimamente governate. ${ }^{28}$ (Giro del Mundo 46)

$\mathrm{He}$ is also correct when he indicates that the Diocese of Manila is the center of spiritual power in the Philippines, created in 1578, under the administration of Nueva Espana. Nevertheless, as a consequence of the complexity of administering the archipelago, on August 14, 1595, Pope Clement VIII approved an order that granted autonomy to the Philippine religious administration, through the establishment of the diocese of Manila and three minor dioceses: Nueva Segovia and Nueva Caceres, ${ }^{29}$ both in Luzon, and the Santisimo Cristo de Jesus in Cebu, which would govern the rest of the Pacific islands dependent on the Spanish Crown.

Gemelli also correctly describes the organizations of temporal power in the Philippines, naming the Captain General as the main authority, as his election was by royal decree, which named him at the instance of the Council of the Indies. As the Crown's representative in the islands, he

${ }^{27}$ There were more municipalities in the Philippines headed by encomenderos and royal functionaries. How ever, they did not have the privileges as in Manila. The government of Manila was founded in 1571 and confirmed by the king in 1595.

${ }^{28}$ Although the Philippine Islands are very far from Europe, and from the court of the Catholic king, our lord, (to whom we happily obey), they are well governed.

${ }^{29}$ Gemelli names Cagayan as the seat of the diocese of Nueva Segovia and Camarines as that of Nueva Caceres (Giro del Mondo 47). The first bishops who served in the indicated dioceses were the Augustinans Pedro de Agusto, Miguel de Benavides, and Francisco de Ortega, who began their terms in 1598, 1599, and 1600, respectively (Montero 174). 
assumed the powers possessed by the monarchy in the Peninsula. Thus, he had the authority over ecclesiastical matters. As a consequence of the Royal Patronage enjoyed by the Crown in the Philippines, he would be the head of the political and military government of the islands, and would preside over the Audiencia in Manila. Gemelli also comments on the evolution of the Audiencia, explaining that the institution was first established in 1584, upon the arrival of the new governor general Santiago de Vera, who hand-carried with him the Royal Decree of May 5, 1583. He further explains that, in 1590, it would be suppressed, and then reestablished permanently in $1598 .{ }^{30}$ Nevertheless, our adventurer errs on one point, when he asserts that the governor general "e dura il suo ufficio otto anni (only serves eight years in office)" (Giro del Mondo 47). In practice, the person who exercised this position could change if the Crown deemed it convenient.

Therefore, if we take into account the importance that the Captain General had in the Philippines, and the weight the Manila Galleon carried in this territory, it is not surprising that he nominated the captains of the galleon every year. This is depicted in Giro del Mondo, which cited Miguel Martinez as the person nominated by Captain General Fausto Cruzat y Gongora-who was the Captain General of the Philippines between 1690 and 1701-to direct the Manila Galleon in 1696. According to the Italian, this governor helped him secure his passage on the Manila Galleon, given his power to distribute tickets. ${ }^{31}$ For this reason, on June 21, 1696 Gemelli visited the modest residence of the governor on the island of San Andres, located half an hour from Manila, to give his thanks (Giro del Mondo 34). He described Cruzat as "uno de migliore Capitane Generali, ch' abbiano avuto l'Isole, dopo la lora conquista (one of the best Captain Generals of the Islands, after the conquest)" (54).

${ }^{30}$ The reasons for these political shifts regarding the Audiencia were due to the pressures exerted by the Spaniards residing in the Philippines after its initial installation. This institution provided obstacles to their activities, which tended to take advantage of the natives, thus exerting pressure on Philip II to suppress it in 1590. However, the desire of Domingo de Salazar to reestablish the said institution was heeded by Philip II, and it was ordered restored in November, 1596. Its permanent reestablishment would take place on June 8, 1598 .

${ }^{31}$ The captain general distributed the tickets, which specified the space on the ships individuals, corresponding to the number of allocated spaces in the vessel. The average number of tickets for each trip was 1500, a big number which corresponded to the captain general, the religious corporations, while other tickets went to individuals privileged by the governor, as in Gemellis's case. These were often widows of Spaniards and retired military officers. Many of them persons sold their tickets to the merchants, who paid them through loans from las obras pías (Montero 224). 
Gemelli's praise is glowing, describing Cruzat's management of the colony as transparent and directed towards strengthening the Hacienda. He notes that Cruzat had eliminated the corruption in the Church, named good mayors, and liquidated the debts of the previous governors. As a matter of fact, Gemelli even ventures the claim that, thanks to Cruzat's management,

...che mentre io era in Manila, stavano in cassa 400. m. pezze d'otto: imperocchè, col suo gran talento, prudenza, zelo, ed applicazione, avea accresciute le rendite del Real Patrimonio in cento e dicci mila pezze d'otto l'anno. (Giro del Mondo 54)

The chronicles of the $18^{\text {th }}$ century corroborate his claim, as Nuno de Villavicencio wrote:

Aviendo propuesto el señor don Fausto Cruçat, siendo gobernador de estas islas, que el augmento de rentas, y ahorro de gastos de que avia arbitrado a favor de la Real Hacienda, importaban en cada un año 110168 pesos, siete tomines y once granos, por real cédula de 6 de marzo de 1700 se mandó descontar dicha cantidad del Real situado (que ya se avia empeçado a practicar en los tres embios anteriores, y quedó minorado en 139831 pesos de grano. (Villavicencio ctd. in Alonso 288)

This citation shows a reality of the political life in the Philippines, the patent dependency of the archipelago on Mexico. On the one hand, it received economic aid from the Crown, ${ }^{32}$ and on the other hand, the Mexican Inquisition possessed power in this part of Southeast Asia. Given this relationship, many historians think that the Philippines was a Spanish colony, but at the same time, a subcolony of Nueva Espana. Through this lens, we should understand the importance of the Manila Galleon, which was the only means used by the Spanish Crown to establish contact with the Islands and the other epicenters of power.

\section{The Politics of Control of the Territories Near Manila}

The entry of Spain's South Sea rivals in the Iberian markets at the end of the $16^{\text {th }}$ century, coupled with the series of events that the Philippines suffered during the Thirty Years War, prompted the Iberian Crown

${ }^{32}$ The situation has been explained by many writers as a strategy of the Spanish Crown to correct budgetary deficits of the government of Manila. Nevertheless, the wealth generated by the Manila Galleon in the Philippines, together with the illegal practices that surrounded the government, resulted in an inefficient government. Alonso Alvarez, after analyzing the fraud found in the budget of Manila (focusing on the study of the native tribute and the right to impose colonial customs tariff), concludes that the administration of Manila did not suffer a deficit. 
to increase her concern for the areas surrounding Manila after the Peace of Westphalia (1648) was signed. According to the $19^{\text {th }}$ century scholar Ferdinand Blumentritt, the Spanish Crown wanted to ensure that, despite the war, the commercial routes that had brought about so many economic benefits would continue to grow. As a matter of fact, until the Peace of Westphalia, the metropolitan authorities of Manila were mainly concerned with extending their powers in the island of Luzon, where Manila is situated. ${ }^{33}$ Their interest in developing the adjacent islands would come later. This can be observed in the text of Gemelli, particularly in Book II of his Volume V, where he alludes to the different areas of concern that preoccupied the governor of Manila at the end of the $18^{\text {th }}$ century, namely Luzon, Visayas, Jolo and Mindanao, Borneo, Mollucas, Marianas, Carolinas and Palaos.

Luzon: As the location of important cities like Manila and Cavite, this island has a leading role in the narration of Giro del Mondo. Undoubtedly, this mortar-shaped island was the most Hispanized of all the Philippine Islands. Despite the power the Spanish forces used to repel the native revolutions and to expand its territories in the $17^{\text {th }}$ century, we should reject the idea that the Spanish Crown completely dominated the island of Luzon (it would not be so even in the $19^{\text {th }}$ century). This reality is present in the narration of Mondo, which alludes to the liberty and autonomy exercised by many indigenous tribes, who did not defer to the decisions taken by the Spanish authorities and even ignored these.

The Visayas: Gemelli describes the group of these central islands in the Philippines by the use of the term Pintadas. ${ }^{34}$ Despite the fact that Spain occupied these islands in the $16^{\text {th }}$ century-as evidenced by the establishment of the Diocese of Cebu-the presence of the Spanish forces in this area was rather scarce during its entire colonial history. This is shown when Gemelli cites the savage acts of one of the communities in the island of Negros, which included communities that maintained their independence from the Spaniards.

Mindanao and Jolo: Gemelli identifies 1597 as the beginning of the Spanish presence in this area, thanks to Esteban Rodriguez Figueroa (Giro del Mondo 237). He mentions that until then, these islands had been dominated by the barbaric Mussulman kings (193). The need to eradicate

${ }^{33}$ According to Gemelli, Luzon in Tagalog means mortar (Giro del Mondo 57). He alluded to the wooden mortar used to pound rice called logsong.

${ }^{34}$ The name came about due to the practice of the inhabitants of "painting" their bodies by means of tattoos and dyeing their beards (Giro del Mondo 132). 
Asian Perspectives in the Arts and Humanities 3.1 (2013): 101-122

piracy from the coasts motivated the government to increase its presence in these islands.

Borneo: Gemelli mentions the peace treaty of Borneo in 1685 (93), signed by Spain to end the acts of piracy, and also indicated the desire of Spain to expand in this area. As a consequence of the nautical course of the Manila Galleon, this territory would undergo an evolution different from the rest of the area, as the North of Borneo, unlike the Moluccas, would form part of Spain's colony until the $19^{\text {th }}$ century. ${ }^{35}$

The Moluccas: As established by Gemelli, this territory would be incorporated to the Iberian Crown as a consequence of the union with Portugal (209). Nevertheless, we should contextualize his statements which may mislead one into thinking that, in 1696, this area was crucial to the government. More accurately, by the end of the $17^{\text {th }}$ century, Spain's interest in controlling this territory from the Philippines had considerably diminished, as a consequence of the growing power of Holland throughout the Moluccas. In fact, Ferdinand Blumentritt cites the year 1689 as the date which marks the separation of Spain and the Moluccas. ${ }^{36}$

Las Marianas: If we observe the attributions that Gemelli grants to his friend, Jose de Milan, and to the Captain General, we can see that he correctly names the date of the definite occupation of this area by the Spanish Crown. Gemelli asserts with certainty the authority of the Philippine head administrator to elect the governor of these islands, which Magellan called "the Land of Thieves" (Giro del Mondo 49). This position had been recently created, after the efforts of Fr. Diego Luis San Vitores to entreat the Crown to concern itself with the evangelization of the Marianas. ${ }^{37}$ The first governor of this territory, Francisco de Irrisari, would not take possession of his post until 1676, when he arrived on the San Antonio (Villaragut). The process of colonization of these islands by the Spanish authorities

${ }^{35}$ Spain did not renounce her rights over Borneo until the Madrid Protocol of March 7 , 1885, and it did so because of international pressure from Germany and the United Kingdom. These powers recognized the Spanish sovereignty over Jolo in exchange for Spain renouncing its claim on the area north of the Moluccas.

${ }^{36} \mathrm{Holland}$, as a consequence of the influence of the Calvinist preacher, Baldaus, embarked on a campaign of repression of the Catholics in Siao. Given this oppression, on October 7 , 1689, Pedro Docoliva arrived in the Philippines to seek the support of the Captain General to put a stop to the Dutch hostile acts. The latter's refusal to help is seen by the historian Blumentritt as a definitive act cutting the union of Spain and the Moluccas.

${ }^{37}$ The Spanish Crown, thanks to the pressure exerted by Mariana of Austria, promulgated the Decree of June 24, 1665, which allows San Vitores to evangelize the Marianas. This priest, after raising funds in Mexico, arrived in the Marianas on board the vessel, La Concepcion in 1668 , to begin the evangelization. 
would end with the promulgation of the Royal Certificate of August 12, 1671 (Brunal Perry 396). In it, the Marianas were assigned a position coming from the Royal Treasury of Nueva Espana. The remittance of the position would be done by the abovementioned Jose de Milan. According to Gemelli, de Milan, whom he described as married and thirty years of age, had planned to stay with him in Cavite before boarding the Galleon. However this did not happen because de Milan left the Philippines before Gemelli, since his task was to deliver the royal assignment while also being charged with exploring the Caroline Islands (Giro del Mondo 244).

The Caroline Islands: Jose de Milan's story serves as a pretext for Gemelli's mention of Lezcano's 1686 discovery of the Caroline Islands (Giro del Mondo 145). Until 1696, little was known about the islands. The attempts to explore the islands, which de Milan would initiate, culminated a year later (1697), thanks to the work of Pedro A. Serrano and Pablo Cain who succeeded in visiting the islands and in establishing a base from which to manage the missions of the archipelago (Coello). Some missions that established in the $18^{\text {th }}$ century by Fr. Cantova failed miserably, proof of Spain's lack of interest in establishing its presence in the area. Spanish disinterest ended only in the final years of the $19^{\text {th }}$ century, as a consequence of the pressure exerted by the Bismarck agreement and the economic interests generated by the Panama Canal.

The Palaos (present-day Palaw): Despite the fact that these islands had been recognized by the 1696 Spanish expeditions, no direct mention of these islands was made in Giro del Mondo. However, Gemelli does allude to the events described by Andres Serrano in his $18^{\text {th }}$ century work, describing this archipelago as marginalized by the Spanish authorities during its entire Spanish colonial history.

Consequently, the case of the Palaos and the Caroline Islands reveals the Spanish Crown's ignorance about many of the islands in the "big Spanish Lake" near the Philippines (Gemelli, Giro del Mondo 56). Moreover, Gemelli shows that this ignorance was not exclusive to Spain. Rather, it extended to all the European powers. This total lack of comprehension of the nature of the islands in the Pacific would last until the $19^{\text {th }}$ century, when the imperialist movement would inspire the world powers to understand the extent of this enormous ocean. Nevertheless, through the Giro del Mondo, we can prove that contemporary Hispanoasia ${ }^{38}$ begins to define itself at the end of the $17^{\text {th }}$ century, taking into account the crucial role

\footnotetext{
${ }^{38}$ Hispanoasia is defined by Leoncio Cabrero as the aggrupation of the Philippines, the Carolines, and the Marianas (Cabrero 17).
} 
played by the navigational route of the Manila Galleon, as a consequence of its economic importance.

\section{The Economic Boom in Philippine Commerce}

The Giro del Mondo describes the Philippines as an area rich in raw material resources, describing it as abundant in gold, wax, cotton, civet, sulphur, cinnamon, cacao, rice, pearls, amber, ${ }^{39}$ fruits, flowers, tobacco, abaca, etc. Given this wealth, it would be easy to think that this Spanish colony would have experienced an economic upturn, especially if we take into account the volume of gold produced-gold being, undeniably, the most highly-valued resource in this period. Gemelli narrates that, according to the Captain General, the entire Philippine territory produced 200,000 pieces of 8 annually, without using mercury (Giro del Mondo 117). However, as Valdes pointed out in the 1990s, even though these islands were rich in gold, this ran out in the initial years of Spanish colonization. This was a crucial factor for the Spanish Crown's occupation of the Philippines. Given the archipelago's strategic geographic location, the Crown decided to strengthen the local economy through commerce-which would influence the merchants near the Philippines to establish themselves firmly in Luzon. In this manner, the archipelago intensified its economic relations with areas in China, Japan, the Middle East, and Southeast Asia.

China: Given the Ming Dynasty's need for silver, they engaged in trade with the Philippines. This gave them access to silver that came to the Philippines from the Americas, a topic extensively discussed in a book by Alfonso Mola and Shaw Martinez. In exchange, China introduced a variety of goods to the Spanish markets, which became popular in European society in the $17^{\text {th }}$ century. These goods included porcelain, which Gemelli features in his narration. He also discussed goods that the Chinese authorities prohibited from export, such as images of a dragon with five griffins, and yellow silk cloth (Gemelli, Giro del Mondo 119; Terracina 387).

Japan: The closure of trade between the Empire of the Rising Sun and Europe in 1639 was a result of the isolation policy Japan developed throughout the era of modernization. It would not open its doors again to the outside world until the Meiji Revolution of 1868. The economic needs of Japan at the time made their self-sufficiency possible. Nevertheless, the effects of the policy of isolation were felt in Manila (Valdes 83-105). Gemelli supports this in his text, where he claims:

\footnotetext{
${ }^{39} \mathrm{Gemelli}$ claims that a piece of amber weighing 100 pounds was found in Jolo (Giro del Mondo 117).
} 
Ailor che fioriva, il commercio col Giappone, venivano quindi ogni anno due, e tre vascelli; e lasciavano argento finissimo, ambra, drappi di seta, forzieri, casse, e tavole di legno prezioso, ottimamente inverniciate; in iscambio di cojame, cera, e frutta del paese. ${ }^{40}$ (Giro del Mondo 119).

Middle East: The products of the Middle East would not arrive in Europe through the Portuguese route that circled Africa, since many articles, proceeding from the Orient, would arrive in the Old Continent through the Manila Galleon, given the economic volume generated by the Philippine commerce. Gemelli attests to this fact by stating

...i diamanti di Gòlconda; rubini, topazj, zaffiri, e la preziosa cannella di Seilon; il pepe della Sammatra, e Giava; il garofalo, e la noche moscata delle Molucche; le perle, é tappeti di Persia; le fine tele, e drappi di seta di Bengala; la canfora di Borneo; il Mengioy, e l'avorio di Camboja; il muschio de los Lequios; le sete, i drappi, le tele, e coltri di cottone; la fina porcellana, ed altre rarità della Cina. ${ }^{41}$ (Giro del Mondo 119)

Southeast Asia: Through the quotation above, we can prove how the Philippines intensified its relations with regions like Cambodia or the Moluccas, given the prosperity of the Galleon and their closeness to Manila. In fact, if we take into account Gemelli's theory regarding the first inhabitants of the Philippines, ${ }^{42}$ we can consider this route as the easiest, given its proximity.

The confluence of these commercial routes in the Philippines brought about the arrival of foreigners who would come to the Philippines for the economic benefits. Giro del Mondo cites many of them, as in the case of the Chinese who arrived in the Philippines, and were called Sangleys. The increase of their population is significant throughout the period of Spanish colonization, especially at the end of the $16^{\text {th }}$ century. This is shown in the

${ }^{40}$ When commerce with Japan flourished, two or three ships yearly would come from Japan, and unloaded fine silver, amber, silks, precious boxes, cajas, coffee and precious wood, beautifully painted, in exchange for leather skins, cueros, wax, and native fruits.

${ }^{41}$ The diamonds from Golconda, rubies, topaz, sapphires, and the precious cinnamon from Ceylon; the pepper from Sumatra and Java; coriander and nutmeg from the Mollucas; pearls and Persian carpets; fine silk cloth from Bengal; camphor from Borneo; the Menguiy and ivory from Cambodia; cotton cloth and fine porcelain, and other exotic products from China.

${ }^{42}$ The Giro del Mondo mentions Tharsis, a native of Java, as the first inhabitant of the Philippines (63). 
following figures, which counted the Chinese population in Manila at 40 in 1570, and at 25,000 in 1603 (Alfonso qtd. in Garcia Abasolo 73).

Gemelli took part in calculating the Chinese population. According to him, there were 3,000 sangleys living in Parian, the Chinese area in Manila, while 40,000 resided throughout the whole Philippines (Giro del Mondo 20). Compared to the figures cited above, there seems to be a marked decline in the Chinese population. The cause of this decline were the repressive measures carried out by the Spanish authorities, who deliberately intended to decrease the number of sangleys, who caused a series of uprisings that altered the Philippine social life. In fact, in 1686, there was an order to expel the sangleys, ${ }^{43}$ which was not followed, as evidenced by the continuing presence of the Chinese during Gemelli's stay in the Philippines. Because the Chinese played an important role in the economy of the whole archipelago, dominating in arts and commerce, the Spanish Crown took only superficial acts of repression. One such act was the prohibition that the sangleys could not keep their lights on at night, which Gemelli alludes to when describing the Parian neighborhood of Manila (Giro del Mondo 22).

The Chinese, however, were not the only foreign group mentioned in Giro del Mondo; it also alludes to communities of the Malays and Japanese. According to Gemelli, many Japanese lived in the Philippines as a consequence of a shipwreck caused by a typhoon in 1690:44

...che andavano con due vesti, larghe come sottane d'abati, e con maniche larghe, \& uguali. quella di sotto era ligata con cinte, attraversate, una dalla parte sinistra, e l'altra per sopra la destra come fanno i cherici spagnuoli. Le brache eran lunghe ,e le scarpe a modo di zoccoli di riformati. Portavano capelli corti, ma rasi sulla fronte, fino alla sommità della testa. ${ }^{45}$ (Giro del Mondo 64)

The presence of these Japanese and other communities not native to the Philippines resulted in a heterogenous society, where a mix of races was the order of the day. Gemelli echoes this complex situation, and to clarify the origin of this population, he prepared a social classification taking into

\footnotetext{
${ }^{43}$ An accord from the Council, passed in Madrid, September 7, 1686 (Ruiz 418).

${ }^{44}$ This data is questioned by Mauro Garcia, as he argues that the date given by Gemelli is too late (31).

${ }^{45}$ They wore two wide outfits that resembled the religious habit of an abbot with wide and even sleeves. The lower piece was tied with crisscrossed strings, one from the left and the other from the right, as used by the Spanish priests. Their stockings were long and their shoes resembled the footwear of the Reformists. They wore their hair short, shaved from the forehead to the crown of the head.
} 
account the ethnic origin of Manila's populace. He classified them according to the following distinctions: Creole-father is Spanish and mother is a Western native; mestizo-father is Spanish and mother is an Oriental native; castizo or terzeron-son of mestizos; cuarteton—father is black and mother us Spanish; mulatto-father is white and mother is black; grifo_black mother and mulatto father; sambo-mother is mulatta and father is native; and cabra-father is sambo and the mother is mulatta (19).

These were the dominant groups of Philippine society, since the Spanish population was small in number. The majority of Spaniards in the archipelago during the colonial period were missionaries, civil servants, and the military, who moved to the islands to practice their professions. Unlike the situation in America, it was not often that they would permanently settle in the islands. In 1876, when the Spanish power was completely consolidated, there were only 3,265 registered Spaniards who resided in the Philippines who did not work for the administration (Cañamaque 25). Consequently, due to the lack of Spaniards, it was logical to think that the system conceptualized by the Crown was a supported, almost totally, by the taxes imposed on the natives, who tended to resort to illegalities and acts of fraud to evade these taxes. This, say the majority of analysts who have studied the Filipino economic system, was the cause of the deficit of the coffers of the Manila treasury. Despite these problems, the Spanish system would continue in the archipelago throughout the Modern Period, mainly due to the great economic benefits brought by the Manila Galleon. Gemelli tries to quantify this, and arrives at the conclusion that this commerce made the Philippines the richest islands in the world:

\section{Può scorgersi quanto il sito di Manila sia atto ad accumulare immense ricchezze, colla mercanzia; poiche un vascello, che di là vada ad Acapulco, nel ritorno vien carico d'argento; guadagnandovisi sino al quattrocento percento. Io per me non credo, che vi siano isole al Mondo più abbondanti..$^{46}$ (Giro del Mondo 119)}

The $400 \%$ profit that Gemelli describes can help us understand the Spanish Crown's continued interest in developing the Manila Galleon's route, which was inaugurated by the vessel San Pedro (which brought Legazpi from Nueva Espana to the Philippines in 1564). ${ }^{47}$ Throughout the second half of the $16^{\text {th }}$ century, based on the promulgation of the decree of January

${ }^{46}$ The amount of wealth that Manila accumulated in goods is evident, because a ship that sails from there to Acapulco returns loaded with silver, allowing profits of $400 \%$. I do not think that there exist other islands richer than these.

${ }^{47}$ See Porras. 
11, 1593, the exclusive right of the Spanish world to deal directly with the Philippines was upheld, with Acapulco as the port of destination. Before the promulgation of this decree, there were a number of areas in America that traded directly with the Philippines. This caused fear among the Spanish merchants, who observed that the profits from the Atlantic monopoly were reduced by the success of the new Oriental market. They protested to the authorities in Spain and asked for the restriction of routes from the South Seas. Due to their influence on the Crown, the Royal Decree of April 14, 1579, was approved. The commerce from Asia would thus be limited to the territories of Nueva Espana, Guatemala and Peru. ${ }^{48}$

However, the Spanish merchants were not satisfied with this measure and clamored for more restrictions on the Oriental market, resulting in the promulgation of the Royal Decree of 1583, which moved for the suspension of the Galleon trade. ${ }^{49}$ The decree of December 18, 1591, prohibited the commercial exchange between the Philippines and Peru, ${ }^{50}$ and finally the decree of January 11, 1593 was issued. This last decree would dictate the defining system of the Galleon trade between Manila and Acapulco, establishing that annually, only two ships could be sent. These two ships would sail together, each ship carrying the maximum of 300 tons. ${ }^{51}$ An additional restriction ruled that the total value of the yearly load should only cost 250,000 pesos; the said quantity would be multiplied by two for the trip from Acapulco to Manila.

This order was greeted with distrust in Manila, which led the authorities, to suspend the implementation of said order until 1605, thus allowing the vessel to overload. The Spanish merchants, learning of this move, protested to the king; as a result, a special commission was sent to the Philippines, headed by Pedro Quiroga, to supervise the cargo of the galleon. This commission complied strictly to its mandate, resulting in discontent among the merchants of Manila and Mexico, who wanted a stop to the supervision. This was achieved on September 30, 1639, and there was an increase of freight on the galleon. Their protests were successful because, in 1702, the value of the merchandise destined for Nueva España was fixed at 300,000 pesos, and at 600,000 pesos on the return trip, aboard two vessels of 500 tons each (Montero 221-22). Although the tonnage was increased, this was not followed, since on several occasions,

\footnotetext{
${ }^{48}$ See Valdes.

${ }^{49}$ This order was worthless since the Viceroy of New Mexico, the Count of A Coruña, did not respect it. See Garcia Abasolo.

${ }^{50}$ See Valdes.

${ }^{51}$ See Bernal.
} 
the weighted load reached 1500 tons per ship due to the lack of control of the authorities. ${ }^{52}$ Despite the possibility of sending two ships, the Manila merchants preferred to use only one, the reason for which is explained in Terracina's study of Giro del Mondo:

The Manila merchants having been granted by the Spanish Court the freedom to load the Galleon and to have another, to serve as convoy, paying each vessel 174,000 pesos, decided, to send only one vessel to avoid paying for two but they constructed ships that would permit the load of three ships. (389)

For this reason, in 1696, only one ship, the San Jose, set sail on its first commercial voyage on the South Seas. The workers of the Cavite Shipyard began construction of this warship in 1694 (Gemelli, Giro del Mondo 249), immediately after a vessel bound for Acapulco (loaded with gold from Masbate, and with the same name) sank in Luban. The capsized ship was

A famous galleon, whose keel was 62 cubits long with a proportionate width, had sunk in 1694 with its crew and cargo. This loss ruined the residents of Manila. The other ship named the Santo Cristo had just added to their misery. These disasters interrupted trade and the Court had to buy a vessel with a keel of 45 cubits constructed in Bargatao to transport the King's effects. (Terracina 389)

During the three centuries of the Manila Galleon route, the San Jose was not the only galleon that sank with all its cargo. Twenty-six shipwrecks caused by bad weather were reported, ${ }^{53}$ among which the sinking of the Encarnacion (which occurred in Bulan, in 1649) is cited in Giro del Mondo (175). Nevertheless, there were four ships during the history of this route that failed to reach their destination due to acts of piracy. Until the $17^{\text {th }}$ century, only the 1587 capture of the Santa Ana by Cavendish in California was recorded. Afterwards, the following ships were captured by the enemies of Spain: the Encarnacion (1709), El Covadonga (1743), and La Santisima Trinidad (1762). Given these dangers, the Crown invested in the construction of ships destined to sail the Pacific route, ensuring their capability to fight against the forces of piracy and of nature. The majority of these ships were constructed in Cavite by Chinese and Malayan laborers.

This was the case with the vessel San Jose, which Gemelli boarded on June 4, 1696, after being aided by the Captain General in securing

\footnotetext{
${ }^{52}$ This is described further in Porras's work.

${ }^{53}$ For further information, see Bernal.
} 
his ticket, and after spending a week preparing for the trip. ${ }^{54}$ However, instead of providing relief, the ship would present more difficulties. In the merchants' greed, they destroyed the water cisterns for the passengers in order to make more space for cargo. In this way, the merchants, "despite the prohibitions from the Court. . loaded the bales on their own, unmindful of the safety of the crew and the passengers, who were exposed to die of thirst in the open sea" (Terrracina 390). With these practices it is no wonder that Gemelli valued the ship's cargo at approximately 50,000 coronas (Giro de Mondo 25).

Having satisfied the wishes of the merchants, finally Gemelli sailed out of Cavite aboard the San Jose on June 29, 1696. He would ply the Pacific waters for almost seven months (he arrived in Acapulco on January 20, 1697), a horrible voyage that brought him to describe the ship as an authentic prison (Giro del Mundo 31).

\section{WORKS CITED}

Felix, Alfonso Jr. The Chinese in the Philippines. Manila: Solidaridad, 1966. Print Alfonso Mola, M. and C. Ma. Shaw Martínez. "La Era de la Plata Española en Extremo Oriente (1550-1700)." España y el Pacífico. Ed. Leoncio Cabrero. Madrid: Información y Revistas, D.L, 1985. 527-42. Print.

Alonso Álvarez, Luis. El Costo del Imperio Asiático: La Formación Colonial de las Islas Filipinas Bajo el Dominio Español, 1565-1806. A Coruña: Historia Económica, 2009. Print.

Bernabeu Albert, Salvador, ed. "Dossier: Los Trabajos y los Días en el Galeón de Manila: El relato de Gemelli Carreri." Anuario de Estudios Americanos. LXIX.1 (2012): 229-312. Print.

Berthe, Jean Pierre. "La Habana de fines del siglo XVII visto por un italiano Gemelli Careri." Revista de la Biblioteca Nacional José Martí. LXII.2 (1972): 62-83. Print.

Blumentritt, Fernando. Ataques de los Holandeses en los Siglos XVI, XVII, XVIII: Bosquejo Histórico por Fernando Blumentritt Traducido del Alemán por Enrique Ruppert. Madrid: Imprenta Fortanet, 1882. Print.

Brunal Perry, Omaira. "Legislación de Ultramar y la Administración de las Marianas: Transiciones y legados." Imperios y Naciones en el Pacífico. Cabrero, Leoncio. "Prólogo." El Galeón de Manila. By W. L. Churz. Madrid: Ediciones de Cultura Hispánica, 1992. 11-30. Print.

Cañamaque, Francisco. Las Islas Filipinas: (de Todo un Poco). Madrid: Librería de Fernando Fé y de Simón y Ostero, 1880. Print.

\footnotetext{
${ }^{54}$ In fact, Gemelli says that seven days before embarkation, he went to Cavite to ensure his boarding and to secure provisions.
} 
Coello, Francisco. La Conferencia de Berlín y la Cuestión de las Carolinas: Discursos Pronunciados en la Sociedad Geográfica de Madrid. Madrid: Librería de Fernando Fé, 1885. Print.

De la Corte y Ruano Calderón, Felipe. Memoria Decriptiva e Histórica de las Marianas y Otras que las Rodean, en Relación con Ellas y su Organización Actual, con Estudios Analíticos de Todos sus Elementos Físicos, Morales y Políticos y Propuesta de su Reforma en Todos sus Ramos para Elevarlos al Grado de Prosperidad que le Corresponden. Madrid: Imprenta Nacional, 1875. Print.

Elizalde Grueso, M. D., J.M. Fradera, and L. Alonso, L., eds. Imperios y Naciones en el Pacífico. Madrid: Consejo Superior de Investigaciones Científicas-Asociación Española de Estudios del Pacífico, 2001. Print.

García Abásolo, A. and R. Pérez Alcalá. "Antonio de Morga. La Visión de Filipinas de un Magistrado Sevillano del Siglo XVI." Actas del Segundo Congreso de Historia de Andalucía, Andalucía y América. Córdoba, 1994. 66-78. Print.

García Abásolo, A. "La Expansión Mexicana Hacia el Pacífico. La Primera Colonización de Filipinas (1570-1588)." Historia Mexicana. XXXII.125 (1982): 44-88. Print.

García de los Arcos, Fernanda. "El Traslado de Novohispanos a Filipinas en la Segunda Mitad del Siglo XVIII." Eds. M. Cristina Barrón and Rafael Ponga. La Presencia Novohispana en el Pacífico Insular: Actas de las Primeras Jornadas Internacionales Celebradas en la Ciudad de México, del 19 al 21 de Septiembre de 1989. México: Universidad Iberoamericana, 1990. 47-70. Print.

Gemelli Careri, Gio Francesco. Giro del Mondo del dottor D. Gio Francesco Gemelli Careri. Parte Quinta Contenente le Cose più ragguardevoli vedute nell'isole Filippine. Naples: n.p., 1700. Print.

---. Viaje a la Nueva España. Trans. J. M. Agreda Sánchez. México: Sociedad de Bibliófilos Mexicanos, 1927. Print.

--- Las Cosas más Considerables Vistas en la Nueva España por el Doctor D. Juan Francisco Gemelli Carreri. Trans. J. M. Agreda Sánchez. México: Xochitl, 1946. Print.

---. A Voyage to the Philippines by Giovanni Francesco Gemelli Careri. Trans. Mauro García. Manila: Filipiniana Book Guild, 1963. Print.

---. Le Mexique a la Fin du XVII Siècle vu par un Voyageur Italien Gemelli Carreri. Trans. Jean Pierre Berthe. Paris: Calmann-Lévy, 1968. Print.

--- Viaje a la Nueva España Estudio Preliminar, Traducción y Notas de Francisca Perujo. Trans. Francisca Perujo. México: UNAM, 1976. Print.

García Luna, M. and José M. Iturriaga. Viajeros Extranjeros en el Estado de México. Toluca: UNAM, 1999. Print.

Herrera Sánchez, Manuel. "Las Indias y la Tregua de los Doce Años." Ed. B. García García. Tiempo de Paces. La Pax Hispánica y la Tregua de los Doce Años. Madrid: Fundación Carlos de Amberes, 2009. 193-229. Print.

Ibáñez y Gracia, Luis de. Historia de las Islas Marianas con su Derrotero, y de las Carolinas y las Palaos, Desde el Descubrimiento por Magallanes en el Año 1521, Hasta Nuestros Días. Granada: Paulino V. Sabatel, 1886. Print. 
Asian Perspectives in the Arts and Humanities 3.1 (2013): 101-122

Miguel Bernal, Antonio. "La Carrera del Pacífico. Filipinas en el Sistema Colonial de la Carrera de Indias. España y el Pacífico." Ed. Leoncio Cabrero. España y el Pacífico: Legazpi. Madrid: Sociedad Estatal de Conmemoraciones Culturales, 2004. 485-525. Print.

Miguel, Gregorio. Estudio Sobre las Islas Carolinas. Madrid: José Perales y Martínez, 1887. Print.

Montero Vidal, José. El Archipiélago Filipino y las Islas Marianas, Carolinas y Palaos. Madrid: Manuel Tello, 1886. Print.

Porras, José Luis. "El Galeón de Manila." Ed. Florentino Rodao. Estudios Sobre Filipinas y las Islas del Pacífico. Madrid: Asociación Española del Pacífico, 1989. 31-40. Print.

Robertson, William. Historia de América. Vol. II. London: n.p., 1767. Print.

Ruíz Rodríguez, Ignacion. Fernando de Valenzuela: Orígenes, Ascenso y Caída de un Duende de la Corte del Rey Hechizado. Madrid: Dyckinson, 2008. Print.

Serrano, Andrés. Noticias de las Islas Palaos. Madrid: n.p., 1705. Print.

Smith, Adam. An Inquiry into the Nature and Causes of the Wealth of Nations. London: W. Strahan, 1778. Print.

Taviel Andrade, Enrique. Historia del Conflicto de las Carolinas. Prueba del Derecho de Soberanía que Sobre ellas Posee España y Demostración de la Trascendencia que Tiene la Mediación del Papa. Madrid: Manuel Tello, 1886. Print.

Terracina, Miguel, trans. "Viages de Gemelli Careri." Historia General de los Viages ó Nueva Colección de Todas las Relaciones de los que se han Hecho por Mar, y Tierra, y se han Publicado Hasta Aora en Diferentes Lenguas. XIX.4 (1763-1790): 330-406. Print.

Valdés Lakowsky, Vera. "Problemas Económicos en el Pacífico." La Presencia Novohispana en el Pacífico Insular: Actas de las Primeras Jornadas Internacionales Celebradas en la Ciudad de México, del 19 al 21 de Septiembre de 1989 83-105. Print.

Villaragut y Esteven, Carlos. Islas Filipinas, Administración de Justicia: Memoria Dedicada a la Exposición Colonial de Amsterdam. Manila: Tipografía de Ramírez y Geraudier, 1883. Print.

Villavicencio, Nuño de. Demostración de Cuerpo de Cargos de la Real Caja de Manila. Manila: n.p., 1737. Print.

David Manzano works in the Spanish National Research Council (CSIC), in the Escuela de Estudios Hispano Americanos Department (Seville, Spain), as a researcher on the Spanish Pacific (Junta de Andalucía, Consejería de Ciencia e Innovación, PO9-HUM-5392, 2010-2013). He graduated with degrees in History (2009) and Political Science (2010) from the University of Granada. His expertise is in the history of international relations, finishing his Master's degrees on Contemporary History (Universidad Complutense de Madrid, 2010) and on Europe, the Mediterranean world and its Atlantic influence (Pablo de Olavide University, Seville, 2012). He has participated in several conferences such as PACLAS 
David Manzano, "Gemelli and His Travel to the Philippines"

in Manila, 2012. He is currently finishing his PhD on the relationship of Spain with the Pacific islands in the $19^{\text {th }}$ century. 